\title{
The Influence of Advanced Paternal Age on Sperm Chromatin Integrity and Early Embryo Morphological Development during ICSI
}

\author{
Mawusi Dickson 1,2, David M. Adedia', Daniel A. Abaye ${ }^{1 *}$ \\ ${ }^{1}$ School of Basic and Biomedical Sciences, University of Health and Allied Sciences, Ho, Ghana \\ ${ }^{2}$ Provita Specialist Hospital Ltd, Tema, Ghana \\ Email: mdickson@uhas.edu.gh,dadedia@uhas.edu.gh, ^dabaye@uhas.edu.gh
}

How to cite this paper: Dickson, M., Adedia, D.M. and Abaye, D.A. (2018) The Influence of Advanced Paternal Age on Sperm Chromatin Integrity and Early Embryo Morphological Development during ICSI. Advances in Reproductive Sciences, 6, 35-49.

https://doi.org/10.4236/arsci.2018.62004

Received: March 21, 2018

Accepted: May 7, 2018

Published: May 10, 2018

Copyright $\odot 2018$ by authors and Scientific Research Publishing Inc. This work is licensed under the Creative Commons Attribution International License (CC BY 4.0).

http://creativecommons.org/licenses/by/4.0/

(c) (i) Open Access

\begin{abstract}
The study determined the impact of advanced male ageing ( $\geq 50$ years) on sperm chromatin integrity and early embryo morphological development in intra-cytoplasmic sperm injection (ICSI) technique cycles. Six hundred subfertile men were age-grouped; $X_{1}$ (50 to 59 years), $X_{2}$ (60 to 69 ), and $X_{3}(\geq 70$ ), were compared with 600 fertile males of known fertility (Y, age 25 - 35 years). Oocytes from 254 women, aged $\leq 30$ years, were included. Sperm were analyzed using acridine orange fluorescence test (AOT) and categorized: "low", "intermediate" and "high" damage. After ICSI, embryos were evaluated and categorized as "good", "fair" or "poor" quality. Embryonic morphological development was assessed at three stages: fertilization, early and late paternal effect. The AOT results were: $X_{1}$ : low $=29$, intermediate $=53$ and high $=118$; $\mathrm{X}_{2}$ : low $=11$, intermediate $=42$ and high $=147 ; \mathrm{X}_{3}:$ low $=8$, intermediate $=24$ and high $=168$; $\mathrm{Y}$ : Low $=486$, intermediate $=71$ and high $=43$. The fertilization rate was: $\mathrm{X}_{1}, 329 / 350$ (93.7\%); $\mathrm{X}_{2}, 298 / 350$ (85.1\%); $\mathrm{X}_{3}, 225 / 350$ (64.1\%) and, $\mathrm{Y}, 350 / 350(100 \%)$. Associations between increasing age and sperm chromatin damage $\left(\chi^{2}(723.249,6) \mathrm{p}<0.0001\right)$, increasing age and inability to fertilize $\left(\chi^{2}(210.990,3) \mathrm{p}<0.0001\right)$ were observed. Associated with increasing age was the significant proportion of morphologically poor quality embryos over the five days after fertilization. Male age $\geq 50$ years, is highly associated with abnormal sperm chromatin organization, an inability to adequately fertilize with ICSI methodology, an increase in the number of poor quality embryos and, a corresponding decrease in the number of good quality embryos five days after fertilization.
\end{abstract}

\section{Keywords}

ICSI, Sperm Chromatin Integrity, Male Age $\geq 50$, AOT, Early Embryo 
Development

\section{Introduction}

Sperm dysfunction is one of the most common causes of male subfertility. Sperm quality has a direct impact on fertilization and embryonic development [1]. In human spermatozoa, the source of chromatin damage may include unresolved strand breaks created during spermatogenesis to relieve the torsional stresses associated with chromatin remodeling, oxidative stress and unsuccessful apoptosis. Chromatin damage is related to a range of unfavorable clinical consequences, including infertility, premature expulsion of the foetus and death of offspring [2]. Immature spermatozoa generate high levels of reactive oxygen species (ROS) which are implicated in chromatin damage and are likely to cause unfavorable arrangements in protamination and chromatin packaging [3].

Single- and double-strand DNA breaks are often detected mostly in the ejaculates of infertile men [4]. Chromatin damage, which includes chromatin fragmentation, abnormal chromatin arrangement, and the lack of the peptide protamine, adversely affects reproductive outcome in natural or unassisted conception [5] and assisted reproduction technology (ART) [4]. Nevertheless, chromatin damage has been detected in spermatozoa from fertile men [6]. Chromatin damage is not only observed in infertile or sub-fertile men, but also in other age related and pathogenic conditions including, genital and systemic infections, cancers, drugs, radio and chemotherapy, hyperthermia, tobacco smoking, and varicocele. These diseased conditions are also associated with changed (high) levels of ROS [7].

Even where the patient is in good health, and thus excluding these factors, paternal age itself is also positively related to the increased chromatin damage in sperm donors and in ageing men of infertile couples [8]. Therefore, the presence of some chromosomal abnormalities in spermatozoa due to increased male age does influence the occurrence of spontaneous miscarriages [9]. When miscarriages occur in women who are 30 years old or less, paternal age greater than 50 years was observed to be a significant factor [10].

Normal chromatin condensation is important in the ability of sperm cells to fertilize eggs and routine semen analysis is not sensitive enough to detect defects in sperm chromatin structure [11]. In in vivo and in vitro studies to determine the influence of paternal aging factor on fertility, a negative relationship has been observed between disorders in the organization of genomic material in sperm nuclei and the fertility potential of spermatozoa [12].

The integrity of the sperm DNA has a direct bearing on successful human reproduction. The work of Sergerie et al. [13] indicated that there appears to be a threshold of sperm DNA damage beyond which fertilization, embryo development and subsequently, pregnancy are impaired. It has been established clinically that sperm DNA impairment has deleterious effects on the outcome of re- 
production, and further, the spermatozoa of infertile men possess substantially more DNA damage than do the spermatozoa of fertile men [14]. The underlying causes of impaired sperm DNA and the consequences on reproductive outcomes in humans remain undeveloped [11].

The goal of the present study is to determine the influence of advanced paternal age on sperm chromatin integrity during intra-cytoplasmic sperm injection (ICSI) technique cycles associated with male factor infertility, and controlling for partner female age. The evaluated parameters were semen quality, i.e. chromatin integrity using acridine orange fluorescence test (AOT); fertilization and embryo cleavage rates and morphological development up to day five after ICSI.

\section{Materials and Methods}

\subsection{Study Design}

This study analyzed the susceptibility of sperm nuclear DNA to acid-induced denaturation in situ by quantifying the metachromatic shift of $\mathrm{AO}$ fluorescence from green (native DNA) to red (denatured DNA). AO is a simple microscopic procedure that is based on the same principle as the sperm chromatin structure assay (SCSA). That is, it is able to evaluate the integrity of the sperm nucleus and disorders of which can cause unexplained infertility or lower fertilization potential that may go undetected by routine semen analysis [15]. The fluorochrome $\mathrm{AO}$ intercalates into double-stranded DNA as a monomer and binds to single-stranded DNA as an aggregate. The monomeric AO bound to native DNA fluorescence green. Aggregated AO on denatured DNA fluoresces red implying damaged DNA and green florescence spots equate to healthy DNA.

Following successful ICSI, the influence of sperm chromatin integrity on early embryonic development was observed and classified into three stages: fertilization rate, early paternal effect (embryonic day 2), and late paternal effect (embryonic days 3 and 5). The morphology of embryos was evaluated using an inverted microscope.

\subsection{The Participants Groups}

The subject selection criteria were based on sub-fertility couples participating in an ICSI program for male factor infertility. The subjects were considered eligible for inclusion in the study if the male partner 1 ) is $\geq 50$ years of age; 2 ) had motile ejaculated spermatozoa during preliminary semen analysis; and 3) on the day of oocyte retrieval, their spouses' age $\leq 30$ years. This is to control for the effect of female age. Couples with male partners whose age were less than 50 years were excluded. Male partners who were $\geq 50$ years but have the following diseased conditions: diabetes, azoospermia, prostatit is, and or had prior cancer therapy were excluded from the study.

\subsubsection{Calculation of the Minimum Sample Size}

We used the rate of chromatin integrity of $50 \%$ for both fertile males and 
sub-fertile males in order to determine the minimum sample size. The sample size was calculated using the formula:

$$
\begin{gathered}
n=\frac{Z_{1-\alpha / 2}^{2}\left(P_{1}\left(1-P_{1}\right)+P_{2}\left(1-P_{2}\right)\right)}{\epsilon^{2}} \\
n=\frac{1.96^{2}(0.5(1-0.5)+0.5(1-0.5))}{0.1^{2}} \cong 193
\end{gathered}
$$

where, $Z_{1-\alpha / 2}=1.96$ is the Reliability coefficient, $P_{1}=P_{2}=50 \%$ is the rate of chromatin integrity in the two major groups (i.e. sub-fertile males $\geq 50$ years and males 25 to 35 years) in addition to the level of precision $(\epsilon)$ of $10 \%$. This gave the minimum sample size, $n$, of 193 participants. Therefore, a total of 600 patients (representing 200 for each subcategory of $\geq 50$ years) were recruited into our study.

The 600 men (aged $\geq 50$ years) of sub-fertile status was further sub-divided by age, $\mathrm{X}_{1}: 50$ to 59 years, $\mathrm{X}_{2}: 60$ to 69 years, and $\mathrm{X}_{3}$ : age $\geq 70$ years. Each group had 200 participants. Another group, Y, served as the control and included 600 young males age 25 - 35 years. The female partners, and volunteer egg donors, age $\leq 30$ years, totaling 254 , took part in the study.

\subsubsection{Ethical Considerations and Informed Consent}

The procedures involved in the study were verbally explained to all participants. Written information for all participants about the purpose of the research and the circumstances that could interfere with the analysis and the interpretation of the results was supplied and explained. Consent was given both verbally and in writing. Relevant information about sample collection and other pertinent issues, for instance, information was sought on recent periods of malaria, fever or inflammatory illnesses and the responses recorded. All participation was entirely voluntary and patients were free to decline to participate. This did not affect their fertility treatment outcome.

The Ethical and Protocol Review Committees of the following institutions unanimously approved of the research proposal on the following dates: the University of Ghana Medical School, Legon, Ghana, December 2nd, 2011; Noguchi Memorial Institute for Medical Research Institutional Review Board (NMIMR-IRB), Legon, Ghana, January 25th, 2012; and the University of Leeds Ethical Review and Clearance Committee, Leeds, UK, February 19th, 2012. The study was conducted during March 2012 and March 2013 at Provita Specialist Hospital in Tema, Ghana.

\section{Samples}

\subsection{Semen Preparation and Analysis}

After semen liquefaction (30 minutes at $37.0^{\circ} \mathrm{C}$ ), macroscopic and microscopic analyses were carried out following the standard operation procedures established by the Hospital. The samples were prepared for sperm selection with G-IVF plus (Vitrolife-Goteborg, Sweden), using the techniques of density gra- 
dient (Irvine Scientific-Santa Ana, CA), "Swim-up" or "Sperm-wash", depending on concentration and motility of each sample.

\subsection{Evaluation of Sperm Chromatin Integrity by AOT}

Fresh semen was smeared on pre-cleaned glass slides, which were air-dried and then fixed in Carnoy's solution (methanol/glacial acetic acid; 3/1; vol/vol) for 2 hours. The fixed slides were then stained with freshly prepared $0.19 \mathrm{mg} / \mathrm{mL}$ of AO (Polysciences, Warrington, PA, USA) for $5 \mathrm{~min}$ in the dark as follows: 10 $\mathrm{mL}$ of $1 \% \mathrm{AO}$ in distilled water were added to a mixture of $40 \mathrm{~mL}$ of $0.1 \mathrm{~m}$ citric acid and $2.5 \mathrm{~mL}$ of $0.2 \mathrm{M} \mathrm{Na}_{2} \mathrm{HPO}_{4} \cdot 7 \mathrm{H}_{2} \mathrm{O}$ buffer and $\mathrm{pH}$ adjusted to 2.5 .

After staining, the slides were rinsed with distilled water to remove excess $\mathrm{AO}$. They were then covered with glass cover slips and immediately evaluated under a fluorescent microscope (Nikon Eclipse E400, Nikon, Japan) at the excitation wavelength of $450-490 \mathrm{~nm}$ and a total magnification of x1000. On average, 200 sperm cells were counted on each slide by the same examiner and the duration of evaluation was not more than $40 \mathrm{sec} /$ field. Spermatozoa with green fluorescence were considered as having normal Chromatin/DNA content, whereas sperm displaying a range of yellow-orange to red fluorescence were considered as damaged Chromatin/DNA. The percentage of spermatozoa with single-stranded DNA was calculated from the ratio of sperm with red, orange, or yellow fluorescence to all sperm counted per sample. AO is for general DNA degradation assessment; whereas the terminal deoxyuridine nick end labeling (TUNEL) technique measures actual single and double stranded breaks [16].

Following AOT, the quality of DNA (extent of DNA damage) was classified into three groups: "low damage" (0\% - 30\%)—thus indicating 30\% denatured DNA (red), "intermediate damage" (31\% - 70\%)-showing 31 to 70 DNA denaturation (red) and "high damage" (71\% - 100\%) showing red.

\subsection{Intracytoplasmic Sperm Injection (ICSI) Methodology}

ICSI was performed in a microinjection dish prepared with $4 \mu \mathrm{L}$ droplets of buffered medium (G-MOPS HEPES, Vitrolife, Goteborg, Sweden) and covered with paraffin oil on the heated $\left(37.0^{\circ} \mathrm{C} \pm 0.5^{\circ} \mathrm{C}\right.$ ) stage of an inverted microscope (Eclipse TE 300; Nikon, Tokyo, Japan) with a Hoffmann modulation contrast system. Approximately 16 hours after ICSI, fertilization was confirmed by the presence of two pronuclei and the extrusion of the second polar body. Embryos were maintained in a $50 \mu \mathrm{L}$ drop of culture medium (G1V5 PLUS, Vitrolife, Goteborg, Sweden) and covered with paraffin oil in a humidified atmosphere under $6 \% \mathrm{CO}_{2}$ at $37^{\circ} \mathrm{C}$. On day 3, embryos were transferred into another culture medium (G2V5 PLUS, Vitrolife, Goteborg, Sweden) for culture up to day 5.

\subsection{Embryo Morphology Evaluation}

Embryo morphology was assessed $16-18 \mathrm{~h}$ post-ICSI and on the mornings of days 2, 3 and 5 using an inverted Nikon under 400X magnification. The embryos 
were then categorized as "good", "fair" or "poor" quality, based on the number and grade of blastomeres. Cleavage stage morphology was assessed based on the following parameters: number of blastomeres, percent fragmentation, variation in blastomere symmetry, presence of multinucleation, and defects in the zona pellucida and cytoplasm.

"Good" quality embryos are cleavage stage embryos showing the following characteristics: 4 cells on day 2 or $8-10$ cells on day $3,<15 \%$ fragmentation, symmetric blastomeres, absence of multinucleation, colorless cytoplasm with moderate granulation and no inclusions, absence of perivitelline space granularity and absence of zona pellucidadysmorphism. Embryos lacking any of these characteristics with fragmentation $<25 \%$ were considered to be of "fair" quality. Poor cleavage stage embryos showed severe fragmentation ( $>25 \%)$ and asymmetrical cells. These embryos were slow growing and contained very low number of cells [17].

In blastocyst formation assessment on day 5 , the embryos were graded using the formation of the inner cell mass (ICM) and the Trophectoderm (TE). Inner cell mass grading; "Good": numerous cells in the epithelium, cells appear healthy and are tightly packed. "Fair": large cells which are loosely packed, and "Poor": few cells, inner cell mass not distinguishable and the presence of degenerative cells. Trophectoderm grading; "Good": many cells forming an epithelium, "Fair": a few large cells forming an epithelium, and, "Poor": a few cells that appear poor or uneven and the presence of degenerative appearance [17] [18].

\subsection{Statistical Analysis}

Pearson's chi square $\left(\chi^{2}\right)$ test of association was used to evaluate the relationship between sperm chromatin damage, fertilization rate and embryo quality rates for each age group. The $t$-test of difference in proportions was also used to compare proportions of fertilization and embryo quality. The results were expressed as proportions, 95\% confidence intervals (CI) for difference in population proportions and p-values. Significance was assigned to events with a p-value $<0.05$. Data analysis was carried out on Minitab Statistical Software (version 17) and SPSS (version 22).

\section{Results}

\subsection{Descriptive Analysis}

A total of 1550 oocytes were retrieved at ovum pick up (OPU) from the 254 women. Of the 1550 oocytes, 377 were donated by 77 women whose male partners were in the group $\mathrm{X}_{1}, 358$ oocytes were from 66 women partnered with male group $\mathrm{X}_{2}, 406$ oocytes were from 51 women with male partners in group $\mathrm{X}_{3}$, and 409 oocytes from 60 women who were partners with the control group, Y. To eliminate potential bias, all the donated oocytes were randomly re-assigned to the four male categories prior to insemination. 


\subsection{Sperm Chromatin Quality and Advanced Male Age}

Chromatin damage in sperm DNA was assessed by the AOT and visualized by fluorescence microscopy (Figures $1(\mathrm{a})$-(c)). The results showed that the number of men exhibiting "high damage", i.e. 70 to $100 \%$ of sperm cells DNA staining red, were $\mathrm{X}_{1}: 118(59 \%), \mathrm{X}_{2}: 147(73.5 \%)$ and $\mathrm{X}_{3}: 168(84 \%)$, out of $200 \mathrm{men}$ in each age category (Table 1 ).

In the control group, Y, $43(7.2 \%)$ men showed "high damage" DNA. In

Table 1. Cross tabulation of sperm chromatin fragmentation and male age groups.

\begin{tabular}{cccccc}
\hline \multicolumn{7}{c}{ Male age groups (years) } & & \\
\hline & $\mathrm{X}_{1}: 50-59$ & $\mathrm{X}_{2}: 60-69$ & $\mathrm{X}_{3}: \geq 70$ & $\mathrm{Y}: 25-35$ & Total \\
\hline Sperm chromatin fragmentation & & & & & \\
Low damage & $29(14.5)^{*}$ & $11(5.5)$ & $8(4)$ & $485(81)$ & 534 \\
Intermediate damage & $53(26.5)$ & $42(21)$ & $24(12)$ & $71(11.8)$ & 190 \\
High damage & $118(59)$ & $147(73.5)$ & $24(12)$ & $43(7.2)$ & 476 \\
Total & 200 & 200 & 200 & 600 & 1,200 \\
\hline
\end{tabular}

${ }^{*}$ Values are actual numbers and per cent $(\%)$. The association between sperm chromatin fragmentation and male age groups is significant $\left(\chi^{2}(723.249,6) \mathrm{p}<0.0001\right)$.

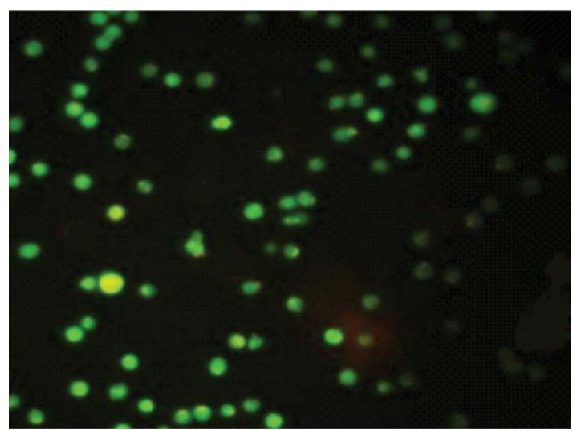

(a)

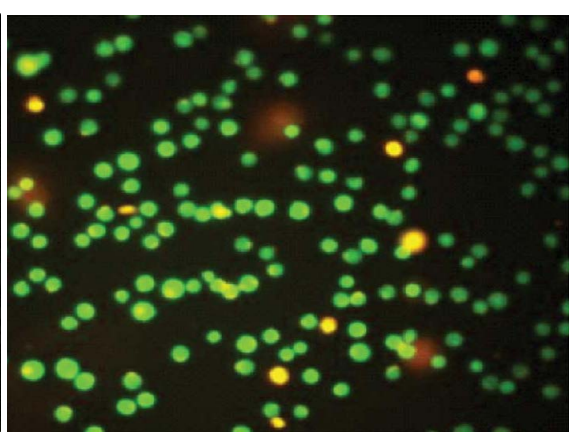

(b)

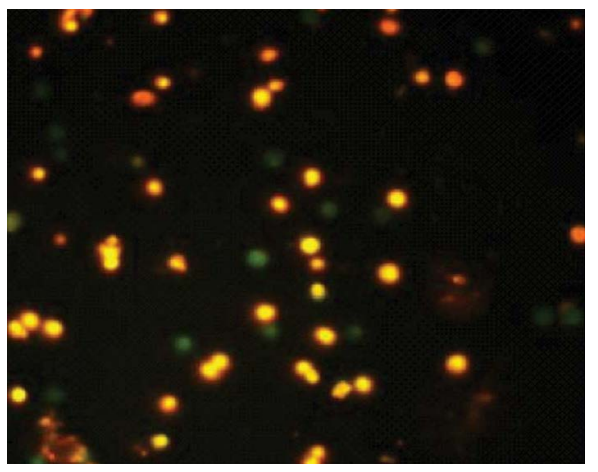

(c)

Figure 1. Chromatin damage in sperm assessed by Acridine Orange Fluorescence staining and visualized using a fluorescent microscope (Nikon Eclipse E400, Nikon, Japan) at the excitation wavelength of $450-490 \mathrm{~nm}$ and a total magnification of x1000. Figure 1(a), Category: 0\% - 30\%-"Low" damaged; (b) Category: 31\% - 70\%—“Intermediate" damaged, and (c) Category: 70\% - 100\%-"High" damaged. 
contrast, the total number of men in each group showing "low damage" DNA (green fluorescence) was $\mathrm{X}_{1}: 29(14.5 \%), \mathrm{X}_{2}: 11(5.5 \%)$ and $\mathrm{X}_{3}: 8(4 \%)$, while in the control group, the number was $486(81 \%)$. The chi squared analysis showed that the association between sperm chromatin fragmentation and increasing male age is significant $\left(\chi^{2}(723.249,6) p<0.0001\right)$ (Table 1$)$.

\subsection{Fertilization Rates and Advanced Male Age}

Following oocyte evaluation, 148 oocytes were found to be defective and therefore, discarded. Of the 1402 oocytes inseminated by ICSI, 200 (14.3\%) oocytes failed to perform normal pronuclei formation, resulting in 1202 fertilized embryos.

The fertilization rate for each male category was: $\mathrm{X}_{1}=329 / 351$ (93.7\%), $\mathrm{X}_{2}=$ $298 / 350$ (85.1\%), $X_{3}=225 / 351$ (64.1\%) and $Y=350 / 350$ (100\%). That is, inability to fertilize was $\mathrm{Y}=0 \%, \mathrm{X}_{1}=6.3 \%, \mathrm{X}_{2}=14.9 \%, \mathrm{X}_{3}=36 \%$ (Table 2).

The association between fertilization status and male age is significant $\left(\chi^{2}\right.$ $(210.990,3) \mathrm{p}<0.0001)$. That is, inability to fertilize was highly associated with increasing age over 50. It should be noted that all the oocytes injected with sperm donated by male group Y (25 - 35 years) were fertilized. The observed differences among the four fertilization rates were significant $\left(\chi^{2}(29.847,3) \mathrm{p}<\right.$ $0.0001)$. Further, the pair-wise $t$-tests between age groups were significant: $X_{1}$ vs. $\mathrm{X}_{2}(\mathrm{p}<0.0001) ; \mathrm{X}_{1}$ vs. $\mathrm{X}_{3}(\mathrm{P}<0.0001) ; \mathrm{X}_{2}$ vs. $\mathrm{X}_{3}(\mathrm{p}<0.0001)$; and, between $\mathrm{Y}$ vs. $\mathrm{X}_{1}(\mathrm{p}<0.0001)($ Table 3$)$.

Table 2. Cross tabulation of fertilization and male age groups.

\begin{tabular}{cccccc}
\hline \multicolumn{5}{c}{ Age groups (years) } \\
\hline $\begin{array}{c}\text { Fertilization state } \\
\text { Fertilized }\end{array}$ & $\mathrm{X}_{1}: 50-59$ & $\mathrm{X}_{2}: 60-69$ & $\mathrm{X}_{3}: \geq 70$ & $\mathrm{Y}: 25-35$ & Total \\
Not Fertilized & $22^{\mathrm{a}}$ & $298^{\mathrm{b}}$ & $225^{\mathrm{c}}$ & $350^{\mathrm{d}}$ & 1202 \\
Total & 351 & $52^{\mathrm{b}}$ & $126^{\mathrm{c}}$ & $0^{\mathrm{d}}$ & 200 \\
\hline
\end{tabular}

There is an association between fertilization status and male age groups $\left(\chi^{2}(210.990,3) \mathrm{p}<0.0001\right)$. The $t$-test of difference in proportionsis significant $(\mathrm{p}<0.05)$ in fertilization among the various male age groups. Different subscripts indicate the differences are significant.

Table 3. Effect of chromatin damage in each category of male group on fertilization

\begin{tabular}{cccc}
\hline Age groups (years) & Observed $\mathbf{N}$ & Expected $\mathrm{N}$ & Residual \\
\hline $\mathrm{X}_{1}: 50-59$ & 329 & 300.5 & 28.5 \\
$\mathrm{X}_{2}: 60-69$ & 298 & 300.5 & -2.5 \\
$\mathrm{X}_{3}: \geq 70$ & 225 & 300.5 & -75.5 \\
Y: $25-35$ & 350 & 300.5 & 49.5 \\
Total & 1202 & & \\
\hline
\end{tabular}

There is a significant difference in the fertilization rates $\left(\chi^{2}(29.847,3) \mathrm{p}<0.0001\right)$, for the four groups. The fertilization rate reduces as the age increases, showing an inverse relationship. 
The fertilization rate reduces as age increases, showing an inverse relationship (Table 3). These results strongly indicate that increasing male age of $\geq 50$ years, is highly correlated with inability to fertilize ova. And therefore, increasing age is associated with chromatin damage, which, in turn is associated with poor fertilization rates.

\subsection{Early Paternal Effect on Embryo Morphological Development}

Early paternal effect was assessed on Day 2 of embryo development (4-cell stage, Figure 2) when the paternal genome is considered to be inactive [19]. When the four insemination groups were evaluated, the number of good quality embryos were $\mathrm{X}_{1}=163, \mathrm{X}_{2}=126, \mathrm{X}_{3}=49$ and $\mathrm{Y}=304$ (Table 4). The differences between each group were significant: $\mathrm{X}_{1}$ vs. $\mathrm{X}_{2}(\mathrm{P}<0.0001)$; $\mathrm{X}_{1}$ vs. $\mathrm{X}_{3}(\mathrm{P}<0.0001) ; \mathrm{X}_{2}$ vs. $\mathrm{X}_{3}(\mathrm{P}<0.001)$; $\mathrm{Y}$ vs. $\mathrm{X}_{1}(\mathrm{P}<0.0001)$. Correspondingly, the number of poor quality embryos were $X_{1}=78, X_{2}=91, X_{3}=225$ and $Y=14$. Therefore, the number of poor quality embryos increased with increasing age.

\subsection{Late Paternal Effect on Embryo Morphological Development}

Late paternal effect was assessed on Days 3 and 5 (Figure 2). At Day 3, the

Table 4. The $\chi^{2}$ test showing the association between age-related chromatin damage and embryo development.

\begin{tabular}{|c|c|c|c|c|c|c|}
\hline Age groups (years) & Embryo quality & Day 2 & Day 3 & Day 5 & Total & $\mathrm{p}$-value \\
\hline \multirow{4}{*}{$X_{1}: 50-59$} & Good & 163 & 125 & 63 & 351 & \multirow{4}{*}{$<0.0001^{\mathrm{a}}$} \\
\hline & Fair & 88 & 62 & 122 & 272 & \\
\hline & Poor & 78 & 142 & 144 & 364 & \\
\hline & Total & 329 & 329 & 329 & 987 & \\
\hline \multirow{4}{*}{$X_{2}: 60-69$} & Good & 126 & 87 & 41 & 254 & \multirow{4}{*}{$<0.0001^{b}$} \\
\hline & Fair & 81 & 76 & 82 & 239 & \\
\hline & Poor & 91 & 135 & 175 & 401 & \\
\hline & Total & 298 & 298 & 298 & 894 & \\
\hline \multirow{4}{*}{$\mathrm{X}_{3}: \geq 70$} & Good & 49 & 38 & 13 & 100 & \multirow{4}{*}{$<0.0001^{\mathrm{c}}$} \\
\hline & Fair & 53 & 40 & 53 & 146 & \\
\hline & Poor & 123 & 147 & 159 & 429 & \\
\hline & Total & 225 & 225 & 225 & 675 & \\
\hline \multirow{4}{*}{ Control Y: 25 - 35} & Good & 304 & 302 & 288 & 894 & \multirow{4}{*}{$=0.439^{\mathrm{d}}$} \\
\hline & Fair & 32 & 34 & 46 & 112 & \\
\hline & Poor & 14 & 14 & 16 & 44 & \\
\hline & Total & 350 & 350 & 350 & 1050 & \\
\hline
\end{tabular}

${ }^{a}$ The embryo quality fertilized by sperm from men within the age group of $50-59$ yrs, decreased significantly over the 5 days after fertilization $\left(\chi^{2}(86.757,4) \mathrm{p}<0.0001\right)$. ${ }^{\mathrm{b}}$ Embryo quality fertilized by sperm from men within the age group of 60-69 yrs decreased significantly over the 5 days $\left(\chi^{2}(69.437,4) \mathrm{p}<0.0001\right)$. ${ }^{c}$ Embryo quality fertilized by sperm from men within the age group of $\geq 70$ years, diminished significantly over the 5 days $\left(\chi^{2}(27.434,4) \mathrm{p}<0.0001\right)$. ${ }^{\mathrm{d}}$ Embryo quality fertilized by sperm from men within the age group $\mathrm{Y}$ did not decrease significantly in the control group over the 5 days $\left(\chi^{2}(3.763,4) \mathrm{p}=0.439\right)$. 
Day 1Oocytes

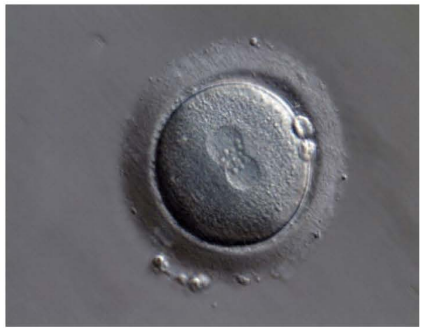

Fertilized oocyte with 2 pronuclei

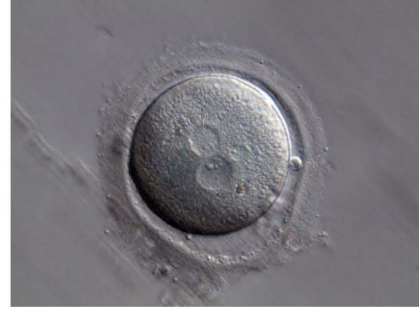

Zygote with two pronuclei

Day 2Embryos

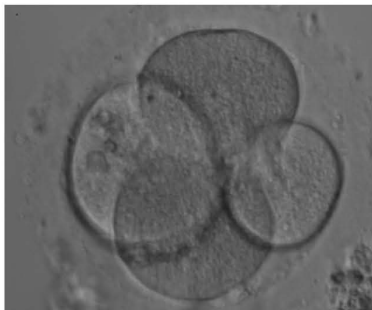

Good

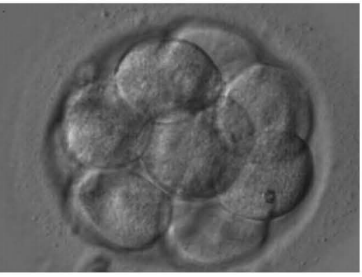

Good

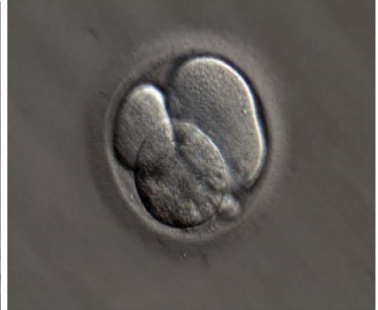

Fair

Day 3 Embryos

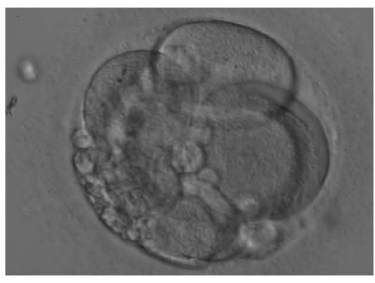

Fair

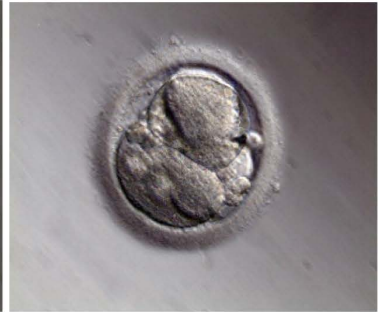

Poor

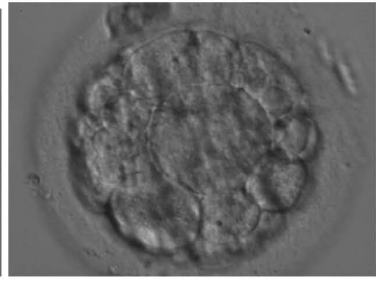

Poor

Day 5 Embryos (Blastocyst stage)

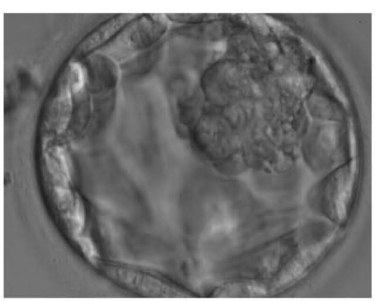

Good

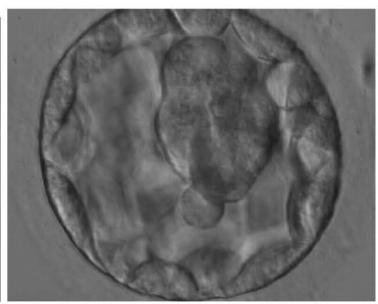

Fair

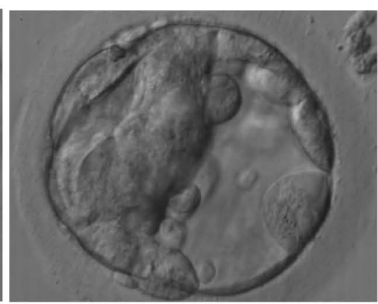

Poor

Figure 2. Morphology and quality of embryos at Days 1, 2, 3 and 5.

number of good quality embryos were, $\mathrm{X}_{1}=125, \mathrm{X}_{2}=87, \mathrm{X}_{3}=38$ and $\mathrm{Y}=302$ (Table 4). Correspondingly, the number poor quality embryos were $X_{1}=142, X_{2}$ $=135, X_{3}=147$, and $Y=14$. At Day 5 , the number of good quality embryos were $\mathrm{X}_{1}=63, \mathrm{X}_{2}=41, \mathrm{X}_{3}=13$, and $\mathrm{Y}=288$. Correspondingly, the number of poor quality embryos were $\mathrm{X}_{1}=144, \mathrm{X}_{2}=175, \mathrm{X}_{3}=159$ and $\mathrm{Y}=16$.

The $\chi^{2}$ analysis indicates that the quality of embryos fertilized by sperm from the $\mathrm{X}_{1}$ group decreased significantly $\left(\chi^{2}(86.757,4) \mathrm{p}<0.0001\right)$ over the 5 day- 
safter fertilization (Table 4). From the $\mathrm{X}_{2}$ group, similarly, the quality of embryos also decreased significantly $\left(\chi^{2}(69.437,4) \mathrm{p}<0.0001\right)$. And from the $\mathrm{X}_{3}$ group, embryo quality also decreased significantly $\left(\chi^{2}(27.434,4) \mathrm{p}<0.0001\right)$ over the five days (Table 4). In contrast, embryo quality in the Y (control) group did not decrease significantly $\left(\chi^{2}(3.763,4) \mathrm{p}=0.439\right)$ over the period. Therefore, decrease in embryo quality increased with advanced age. That is, there is a positive association between poor quality embryos and increasing age over 50 years. The $95 \%$ confidence intervals and $t$-test of proportions of embryo quality rates for age each group are given in Supplementary Material.

\section{Discussion}

Although, the paternal influence of damaged chromatin was observed at all embryonic developmental stages (pronuclei-zygote stage, cleavage stage, morula stage and the blastocyst stage) we found a more prominent paternal effect after embryonic genome activation had occurred, at embryonic stage Day 3.

During ICSI procedures, a failure to fertilize may be related to defective sperm and or oocyte. The quality of both oocytes and sperm has previously been associated with diminished fertilization [19]. Sperm with chromatin fragmentation, nevertheless, can undergo successful fertilization, pronuclear formation and syngamy. It is note-worthy that in the male age groups $X_{2}(60-69)$ and $X_{3}(\geq 70$ years), $15 \%$ and $36 \%$ of the oocytes, respectively, failed to fertilized with ICSI. Therefore, our work is in agreement with that of Greco et al. [19], in that, poor quality sperm is directly related to a decrease in fertilization rates, and is directly related to increasing paternal age over 50 years.

Development of the embryo post-fertilization depends on a reserve of maternal mRNA accumulated during oocyte growth and maturation [20]. Significant transcription of the embryonic genome only takes place after the 4-cell stage in humans [21]. In our study, again, at day 2, we observed an increase in the number poor quality embryos with increasing age over 50 years. Although the effect of sperm chromatin damage is more apparent in later stages of embryogenesis (Day 5), it is not likely to be due to paternal gene expression abnormalities, as the embryonic genome is not yet activated. Harrouk et al. [22] reported that paternal chromatin damage might be translated into chromosome aberrations after the first metaphase.

We showed that on Day 3 and Day 5 of culture post-fertilization, there was a significant decrease in the percentage of good quality embryos and an increase in the percentage of poor quality embryos, with increased sperm chromatin damage. Our study showed that, increasing paternal age $\geq 50$ years is highly associated with sperm chromatin damage, which, in turn is associated with poor fertilization rates when ova were obtained from women $\leq 30$ years. Using ova from female partners or donors at $\leq 30$ years is important as it eliminates the confounding factor of the influence of age in females in the study.

The proportion of poor quality embryos at days 3 and 5 was highly associated 
with increasing paternal age. Chromatin damage can affect a wide variety of cellular processes, including chromatin repair mechanisms, transcription and cell cycle control [23]. Thus, it is possible that extensive paternal chromatin damage could affect these normal embryonic cell processes. Oocytes can repair some damaged chromatin [24]. However, if the level of chromatin damage exceeds the capacity of the oocyte to completely repair the damage, then the cell might undergo apoptosis.

Our study showed that the progression of development from good quality day 3 embryos to day 5 embryos (blastocysts) is highly influenced by the level of sperm chromatin damage. It was previously observed that faster dividing cleavage stage embryos more often develop into blastocysts, and are associated with higher pregnancy rates [25]. We reasoned that high sperm chromatin damage levels are directly related to embryonic cleavage rates, such that the activation of additional chromatin repair pathways forces delays in cell division resulting in a poor quality blastocyst, an observation similarly reported [24]. The high success rate achieved by ICSI has led some to suggest that ICSI should be performed for all ART cases as the embryo quality depends on intrinsic factors of the gametes, rather than the fertilization process [26] [27]. This is supported by the observation that sperm chromatin damage maybe associated with sperm morphology [28] [29].

The AO staining method results confirm the findings using other assays, that higher sperm chromatin damage is associated with lower embryo quality, increased embryo development arrest and decreased pregnancy rates, while lower sperm chromatin damage is associated with higher embryo quality, better embryo development and increased pregnancy rates [30] [31].

\section{Limitations of This Study}

Cohan et al. [32] reported that the AOT is not a good predictor of DNA damage. That is, both the SCSA and TUNEL techniques are more sensitive to DNA chromatin damage assessment than the AOT. At the time of this study, the hospital laboratory (at Tema, Ghana) did not have the expertise or a flow cytometer equipment to either perform the SCSA or TUNEL tests. Nevertheless, the results presented here are conclusive and compelling, and, in agreement with those of Virro et al. [33], that DNA fragmentation analysis by SCSA can be utilized as a predictor for IVF/ICSI outcomes. These results are also supported by an in vivo study [34] where DNA fragmentation correlates with fertility status, time to pregnancies and spontaneous miscarriages.

\section{Conclusion}

Our findings indicated a significant association between paternal age $\geq 50$ years and the following measures; higher levels of chromatin damage in sperm DNA, an inability to adequately fertilize ova from females aged $\leq 30$ years, and a high proportion of morphologically poor quality embryos in all stages of early em- 
bryonic development following fertilization to day 5 . These observations were most prominent in the oldest age group ( $\geq 70$ years).

\section{Acknowledgements}

We acknowledge and thank Prof. Helen Picton, Prof. Dr.Med. Ricardo Felberbaum, Dr. John Huntriss, Dr. Joseph Mainoo, Jan Hogg, and Mr. Mohammad Kousehlar (Klinikum Kempten, Germany) for their advice and expertise. The laboratory expertise of the following technologists is greatly appreciated: Mohammed Kamal (Airport Women's Hospital, Accra, Ghana), Muller M. Mawusi, Luke Mawusi and Karen Mawusi (Tema, Ghana).

\section{Conflicts of Interests}

We declare no conflicts of interests.

\section{References}

[1] Naina, K. and Amit K.S. (2015) Trends of Male Factor Infertility, an Important Cause of Infertility: A Review of Literature. Journal of Human Reproduction Science, 8, 191-196. https://doi.org/10.4103/0974-1208.170370

[2] Aitken, R.J. and De Iuliis, G.N. (2010) On the Possible Origins of DNA Damage in Human Spermatozoa. Molecular Human Reproduction, 16, 3-13. https://doi.org/10.1093/molehr/gap059

[3] Olivia, R. (2006) Protamination and Male Infertility. Human Reproduction Updates, 12, 417-435. https://doi.org/10.1093/humupd/dmlo09

[4] Oliveira, J.B. and Franco Jr., J.G. (2007) The Effects of Male Age on Sperm DNA Damage in an Infertile Population. Reproductive BioMedicine Online, 15, 514-519. https://doi.org/10.1016/S1472-6483(10)60382-3

[5] Spano, M., Bonde, J.P., Hjollund, H.I., Kolstad, H.A., Cordelli, E. and Leter, G. (2000) Sperm Chromatin Damage Impairs Human Fertility. The Danish First Pregnancy Planner Study Team. Fertility and Sterility, 73, 43-50.

[6] Zini, A. and Libman, J. (2006) Sperm DNA Damage: Clinical Significance in the Era of Assisted Reproduction. Canadian Medical Association Journal, 175, 495-500. https://doi.org/10.1503/cmaj.060218

[7] Vagnini, L., Baruffi, R.L., Mauri, A.L., Petersen, C.G., Massaro, F.C., Pontes, A., Oliveira, J.B. and Franco Jr., J.G. (2007) The Effects of Male Age on Sperm DNA Damage in an Infertile Population. Reproductive BioMedicine Online, 15, 514-519. https://doi.org/10.1016/S1472-6483(10)60382-3

[8] Wyrobek, A.J., Eskenazi, B., Young, S., Arnheim, N., Tiemann-Boege, I., Jabs, E.W., Glaser, R.L., Pearson, F.S. and Evenson, D. (2006) Advancing Age Has Differential Effects on DNA Damage, Chromatin Integrity, Gene Mutations, and Aneuploidies in Sperm. Proceedings of the National Academy of Sciences of the United States of America, 103, 9601-9606.

[9] Singh, N.P., Muller, C.H. and Berger, R.E. (2003) Effect of Age of DNA Double-Stranded and Apoptosis in Human Sperm. Fertility and Sterility, 80, 1420-1430. https://doi.org/10.1016/j.fertnstert.2003.04.002

[10] Chen, H., Liao, S.B., Cheung, M.P.L., Chowc, P.H., Cheung, A.L.M. and Sum, W. (2012) Effects of Sperm DNA Damage on the Levels of RAD51 and p53 Proteins in Zygotes and 2-Cell Embryos Sired by Golden Hamsters without the Major Acces- 
sory Sex Glands. Free Radical Biology and Medicine, 53, 885-892. https://doi.org/10.1016/j.freeradbiomed.2012.06.007

[11] Agarwal, A. and Allamaneni, S.S. (2005) Sperm DNA Damage Assessment: A Test Whose Time Has Come. Fertility and Sterility, 84, 850-853.

https://doi.org/10.1016/j.fertnstert.2005.03.080

[12] Bungum, M., Humaidan, P. and Axmon, A. (2007) Sperm DNA Integrity Assessment in Prediction of Assisted Reproduction Technology Outcome. Human Reproduction, 22, 174-179. https://doi.org/10.1093/humrep/del326

[13] Sergerie, M., Laforest, G. and Bujan, L. (2005) Sperm DNA Fragmentation: Threshold and Value in Male Fertility. Human Reproduction, 20, 3446-3451. https://doi.org/10.1093/humrep/dei231

[14] Borini, A., Tarozzi, N. and Bizzaro, D. (2006) Sperm DNA Fragmentation: Paternal Effect on Early Post-Implantation Embryo Development in ART. Human Reproduction, 21, 2876-2881. https://doi.org/10.1093/humrep/del251

[15] Ajina, T., Ammar, O., Haouas, Z., Sallem, A., Ezzi, L., Grissa, I., Sakly, W., Jlali, A. and Mehdi, M. (2017) Assessment of Human Sperm DNA Integrity Using Two Cytochemical Tests: Acridine Orange Test and Toluidine Blue Assay. Andrologia, 49, e12765. https://doi.org/10.1111/and.12765

[16] Sharma, R.K., Sabanegh, E., Mahfouz, R., Gupta, S., Thiyagarajan, A. and Agarwal A. (2010) TUNEL as a Test for Sperm DNA Damage in the Evaluation of Male Infertility. Urology, 76, 1380-1386. https://doi.org/10.1016/j.urology.2010.04.036

[17] Ryan, J., Heitmann, R.J., Hill, M.J., Richter, K.S., DeCherney, A.H. and Widra, E.A. (2013) The Simplified SART Embryo Scoring System Is Highly Correlated to Implantation and Live Birth in Single Blastocyst Transfers. Journal of Assisted Reproduction and Genetics, 30, 563-567. https://doi.org/10.1007/s10815-013-9932-1

[18] Racowsky, C., Vernon, M. and Mayer, J. (2010) Standardization of Grading Embryo Morphology. Journal of Assisted Reproduction and Genetics, 27, 437-439. https://doi.org/10.1007/s10815-010-9443-2

[19] Greco, E., Scarselli, F., Iacobelli, M., Rienzi, L., Ubaldi, F. and Ferrero, S. (2005) Efficient Treatment of Infertility due to Sperm DNA Damage by ICSI with Testicular Spermatozoa. Human Reproduction, 20, 226-230.

https://doi.org/10.1093/humrep/deh590

[20] Telford, N.A., Watson, A.J. and Schultz, G.A. (1990) Transition from Maternal to Embryonic Control in Early Mammalian Development: A Comparison of Several Species. Molecular Reproduction and Development, 26, 90-100.

https://doi.org/10.1002/mrd.1080260113

[21] Simon, L., Liu, L., Murphy, K., Ge, S., Hotaling, J. and Aston, K.I. (2014) Comparative Analysis of Three Sperm DNA Damage Assays and Sperm Nuclear Protein Content in Couples Undergoing Assisted Reproduction Treatment. Human Reproduction, 29, 904-917. https://doi.org/10.1093/humrep/deu040

[22] Harrouk, W., Robaire, B. and Hales, B.F. (2000) Paternal Exposure to Cyclophosphamide Alters Cell-Cell Contacts and Activation of Embryonic Transcription in the Preimplantation Rat Embryo. Biology of Reproduction, 63, 74-81. https://doi.org/10.1095/biolreprod63.1.74

[23] Jackson, S.P. and Bartek, J. (2009) The DNA-Damage Response in Human Biology and Disease. Nature, 461, 1071-1078. https://doi.org/10.1038/nature08467

[24] Bazrgar, M., Simon, L., Murphy, K., Shamsi, M.B., Liu, L., Emery, B., Aston, K.I., Hotaling, J. and Carrell, D.T. (2014) Paternal Influence of Sperm DNA Integrity on Early Embryonic Development. Human Reproduction, 29, 2402-2412. 
|https://doi.org/10.1093/humrep/deu228

[25] Knez, K., Tomazevic, T., Vrtacnik-Bokal, E. and Virant-Klun, I. (2013) Developmental Dynamics of IMSI-Derived Embryos: A Time-Lapse Prospective Study. Reproduction Biomedicine Online, 27, 161-171. https://doi.org/10.1016/j.rbmo.2013.04.002

[26] Fishel, S., Aslam, I., Lisi, F., Rinaldi, L., Timson, J., Jacobson, M., Gobetz, L., Green, S. and Campbell, A. (2000) Should ICSI Be the Treatment of Choice for All Cases If In-Vitro Conception? Human Reproduction, 15, 1278-1283. https://doi.org/10.1093/humrep/15.6.1278

[27] Oehninger, S., Morshedi, M., Weng, S.L., Taylor, S., Duran, H. and Beebe, S. (2003) Presence and Significance of Somatic Cell Apoptosis Markers in Human Ejaculated Spermatozoa. Reproductive BioMedicine Online, 7, 469-476. https://doi.org/10.1016/S1472-6483(10)61892-5

[28] Evenson, D.P. and Wixon, R. (2006) Meta-Analysis of Sperm DNA Fragmentation Using the Sperm Chromatin Structure Assay. Reproductive BioMedicine Online, 12, 466-472. https://doi.org/10.1016/S1472-6483(10)62000-7

[29] Sakkas, D. and Alvarez, J.G. (2010) Sperm DNA Fragmentation: Mechanisms of Origin, Impact on Reproductive Outcome, and Analysis. Fertility and Sterility, 93, 1027-1036. https://doi.org/10.1016/j.fertnstert.2009.10.046

[30] Seli, E.S., Gardner, D.K., Schoolcraft, W.B., Moffat, O. and Sakkas, D. (2004) Extent of Nuclear DNA Damage in Ejaculated Spermatozoa Impacts on Blastocyst Development after in Vitro Fertilization. Fertility and Sterility, 82, 378-383. https://doi.org/10.1016/j.fertnstert.2003.12.039

[31] Evenson, D.P., Larson, K.L. and Jost, L.K. (2002) Sperm Chromatin Structure Assay: Its Clinical Use for Detecting Sperm DNA Fragmentation in Male Infertility and Comparisons with Other Techniques. Journal of Andrology, 23, 25-43. https://doi.org/10.1002/j.1939-4640.2002.tb02599.x

[32] Chohan, K.R., Griffin, J.T., Lafromboise, M., De Jong, C.J. and Carrell, D.T. (2006) Comparison of Chromatin Assays for DNA Fragmentation Evaluation in Human Sperm. Journal of Andrology, 27, 53-59. https://doi.org/10.2164/jandrol.05068

[33] Virro, M.R., Larson-Cook, K.L. and Evenson, D.P. (2004) Sperm Chromatin Structure Assay (SCSA) Parameters Are Related to Fertilization, Blastocyst Development, and Ongoing Pregnancy in in Vitro Fertilization and Intracytoplasmic Sperm Injection Cycles. Fertility and Sterility, 81, 1289-1295. https://doi.org/10.1016/j.fertnstert.2003.09.063

[34] Evenson, D.P. and Wixon, R. (2008) Data Analysis of Two in Vivo Fertility Studies Using Sperm Chromatin Structure Assay-Derived DNA Fragmentation Index vs. Pregnancy Outcome. Fertility and Sterility, 90, 1229-1231.

https://doi.org/10.1016/j.fertnstert.2007.10.066 